\title{
Revisiting Baroque Poetics in Fernão Mendes Pinto’s Peregrinação: The Hermeneutics of Worldview
}

\section{Catarina Fouto}

King's College London

\begin{abstract}
This paper explores the Baroque poetics of Fernão Mendes Pinto’s Peregrinação. Drawing from Roland Greene's Five Words, it argues that the shift in worldview that occurred between the late sixteenth century and the early seventeenth century played a crucial role in the development of Baroque poetics, style and commonplaces, and, crucially, that these should be seen as powerful hermeneutic tools. Whilst addressing the critical debate surrounding certain features of the Peregrinação, this paper focuses on questions of generic hybridity, encoded polyphony, and spectacle from a multidisciplinary approach. Through a close reading of certain episodes of the Peregrinação, this paper highlights the discursive power of this text in problematizing and disrupting stable views of the world and the moral and cultural superiority of the Portuguese and their imperial aspirations.
\end{abstract}

Keywords: Critical semantics, Peregrinação, Baroque poetics, generic hybridity, polyphony, spectacle.

After its initial publication in 1614, Fernão Mendes Pinto's Peregrinação was rapidly translated into several European languages, to the delight of cultivated audiences eager for news of the exotic Orient, its peoples, cultures, and customs. The first Spanish translation, the work of Castilian humanist and orientalist Francisco de Herrera Maldonado, was published in 1620; another Herrera Maldonado edition would appear seven years later, followed 
quickly by other Spanish editions as well as multiple editions in Dutch, English, French, and German. A second Portuguese edition would appear in 1678 (Wojciehowski 169).

If modern critical analyses of the Peregrinação begin with the trailblazing work of Hernâni Cidade and António José Saraiva in the last century, the past few decades have seen an increased interest in Mendes Pinto's text, and these critics have approached it from many thought-provoking perspectives. Among these, one highlight is Maria-Alzira Seixo's reading of the Peregrinação in the context of her broader concern with Baroque and Mannerist poetics and postcolonial approaches to early modern travel writing. ${ }^{1}$ Seixo underscores the development of a variety of genres of travel writing, prompted by the experience of Portuguese travels:

O caso da literatura portuguesa, procedendo, em novas formas de discurso, dos descobrimentos marítimos, cabe justamente numa situação específica dessa natureza que envolve propostas genológicas diferenciadas, ora praticando processos de escrita técnica da arte da navegação (diário de bordo), ora desenvolvendo um género pragmático (os roteiros) ... ora ainda constituindo pequenos corpus [sic] de narrativas peculiares de organização idêntica (os relatos de naufrágios) ou textos singulares de carácter híbrido que só muito recentemente se encontraram sancionados pela convenção literária vigente (a Peregrinação). (Poéticas da Viagem 55, emphasis mine)

Seixo raises an important point insofar as she draws attention to the generic hybridity of the Peregrinação, even if her comparative analysis of the História Trágico-Marítima and the Peregrinação (the two most famous examples of travel writing in Portuguese literature) does not fully develop this thesis. She goes on to affirm that:

... o eixo de incerteza entre veracidade e ficção que orienta a escrita-leitura destes textos ...-verdade dos acontecimentos, ficção na orgânica da narrativa, na retórica dos processos de escrita, na poética dos seus elementos semântico-estilísticos—abre possibilidades de fissura no 
compartimento estanque que a época nos fornece e onde se arrumam os géneros propriamente literários e os géneros de composição pragmática.

(Poéticas da Viagem 57)

Seixo argues convincingly that the notion of "adventure" is central to the Peregrinação, and she characterizes its generic hybridity as a mixture of "pragmatic" concerns and "literary" ones. Beyond this, she compares and contrasts the different features of Baroque and Mannerist sensibilities in both the História Trágico-Marítima and the Peregrinação.

While I agree with Seixo's central thesis (that the Peregrinação is a hybrid text deeply informed by Baroque sensibilities), it is necessary to go further. As I see it, both the generic hybridity and polyphonic discourse of the Peregrinação are intrinsically linked to the shift in worldview brought about at the end of the sixteenth century. It is this shift that ultimately led to the development of what we recognize as Baroque style and poetics, and so it makes sense to direct our critical focus toward developing a contextualized, hermeneutic account of Baroque poetics, style, and commonplaces themselves, as well as how these are manifested within the Peregrinação and to what effect. Of particular concern to the present study is the deeper meaning of particularly Baroque forms of generic hybridity, polyphony, and spectacle in Mendes Pinto's text and the effect that these might have had upon the Peregrinação's seventeenth-century readers.

\section{New Worlds, New Worldviews}

Many factors contributed to a shift in worldview in the sixteenth century, from the schism of the Church and the Counter-Reformation to the political crises that plagued sixteenth-century Europe. Also significant was an epistemological revolution brought about by European expansion into the Americas and Asia. The spirit of confidence in the humanist values of the Renaissance eroded quickly, prompting paradoxical feelings of skepticism about and fervent belief in the transcendental. The genesis of these transformations is well illustrated in Hans Holbein's The Ambassadors (1533), now hanging in the National Gallery in London. The painting presents two male figures, a layman and a cleric (their identities are still subject to some debate) who look at the observer while 
surrounded by objects and instruments representative of the spirit of their age. Both men appear to have an enthusiastic interest in mathematics, astronomy, and geography, as they surround themselves with a globe (on the bottom shelf), a celestial sphere, a quadrant, and different sundials. The detail of the globe represents the epistemological horizons of the knowledge of the world: Europe, Africa, part of the Americas, Western Asia, and part of India. A book on commercial arithmetic by the German scholar Peter Apian sits by the globe, a symbol of European commercial interests in an increasingly global world. But the harmony of the painting is broken by other more disturbing and subtle elements: next to the globe rests an upside-down lute with a broken string. This suggests discord, confirmed by the appearance of an open Lutheran hymnal, which alludes to the religious strife that then divided Christianity. The viewer also puzzles over the odd-shaped figure at the lower centre of the painting and must change perspective altogether to see finally the distorted skull of significant proportions that jumps out of the painting as a powerful memento mori. Following the angle of the distorted skull, one finds a crucifix hanging in the upper left-hand corner of the painting, almost hidden by the sumptuous setting. It is this dramatic shift in perspective, necessary for a full engagement of Holbein's multi-layered painting, that has most directly prompted me to revisit the Peregrinação and to adopt a multi-faceted approach revolving around questions of worldview in the late sixteenth and early seventeenth centuries.

As Roland Greene has recently argued, the expansion of epistemological horizons that occurred in the fifteenth and sixteenth centuries had a significant impact on the very conceptualization of the world ("The Global I," Five Words). The "New Worlds" that were progressively unveiled before the eyes of Europeans emerged for the latter as spaces of Otherness that, through their alterity and complexity, challenged the limits of knowledge and a univocal perspective of the world. Mapping the semantic evolution of the concept of "world" (and "selfhood"), Greene has established a direct link between the revolution brought about by overseas expansion and the ways in which such expansion complicated, over the second half of the sixteenth century, the very concept of "world" itself: "No longer necessarily the oikoumene (the inhabited world) or the kosmos, ambiguated by possibilities such as partiality and multiplicity, the 
world as a concept comes to float free of its stock meanings" (Five Words 153). As Greene has it, early modern intellectuals imbued with a more established worldview indebted to Aristotelian and Ptolemaic cosmology often juxtaposed and combined these new ways of perceiving the world as partial, multiple, abstract, and constructed with received notions of the world as whole, singular, corporeal, and natural (Five Words 151-53). Such a compound and even conflicted worldview finds itself reflected in the writing of these intellectuals in profound ways, and in the effect that their writing had on readers: "A writer who sees multiple worlds and ... all of them partial, such as Cervantes, is probably interested in exploring literary models that allow for a progressive decentering of power and knowledge" (Greene, Five Words 154).

My interest in Greene's critical appreciation of Cervantes's prose may at first seem to have little to do with Mendes Pinto's written work. The fantasy world of Quixote and his parodied chivalric ideals/adventures are a stark contrast to Mendes Pinto's travels in the East and his openly pragmatic approach to his many adventures and catastrophes; however, the works share a similar worldview. That is, in both the Peregrinação and Don Quixote, "the complexity of the observed world is often greater than that of the observing self" (Greene, "The Global I" 173). In the case of the Peregrinação, the subject is quite literally displaced from his own socio-cultural sphere, with all the Bakhtinian consequences that I explore below. $^{2}$

An attentive reading of the Peregrinação reveals that within the text the word mundo is never equivalent to universe or kosmos, or even to oikoumene. In a specifically geographical sense, it is a space composed of different parts, as the author refers to on more than one occasion, and famously at the beginning of his wanderings:

... fui treze vezes cativo, e dezassete vendido, nas partes da India, Etiópia, Arábia felix, China, Tartária, Macassar, Samatra, e outras muitas províncias daquele oriental arcipelago, dos confins da Ásia, que os escritores Chins, Siames, Gueos e Lequios nomeão nas suas geografas por "pestana do mundo," como ao diante espero tratar muito particular, e muito difusamente .... (chap. 1$)^{3}$ 
This conceptualization of the world as partial is further reinforced by the geographical relativism that surfaces in the text. The "pestana do mundo" (literally, the "edge of the world," or the extent of Portuguese imperial ambitions) here refers to Eastern Asia, and it is connected throughout the Peregrinação to "cabo do mundo," "the end of the world," always used to indicate Portugal. ${ }^{4}$ Another clear example of this can be found in Ch. 135 of the Peregrinação: in a letter sent by king of Bungo to the prince of Tanegashima, the Portuguese are referred to as "Chenchicogins do cabo do mundo". Etymologically, the term "Chenchicogins" is a compound of "tenjiku" (India) and "jin" (person), i.e. "Indians". Therefore, in the letter, the Portuguese are defined quite literally as "Indians from the end of the world." Labels such as these signal the existence of different worlds in the Peregrinação, worlds which had recently been connected by networks of political and commercial interests. This shift, effectively a geographical decentering, serves also to foreground the existence of multiple (often conflicting) points of view within the text, and the decentering of power within it. In this way, Mendes Pinto refers to China as "este imperio, ou monarchia, ou como lhe quiserem por o nome (porque na verdade todo o que for grande the cabe)" and to Beijing as the "metropoli da Monarchia do mundo" (Ch. 105). One should note here the use of mundo in its imperial Chinese sense.

\section{Other Worlds, Hybrid Genres}

On one level, it is true that Mendes Pinto projects a recognizably European gaze onto Asia's topography, flora, fauna, and peoples; this has led more than one critic to refer to the Peregrinação as a kind of predecessor to modern European exoticism and Eurocentric ethnographic accounts of the East (Arnaud; Margarido; Rubiès). In his introductory chapter, Mendes Pinto warns the reader that he will be exhaustive in his narrative ("espero tratar muito particular, e muito difusamente"), drawing attention to how the extent of his experiences and the novel world he encountered could only be done justice by inscribing copia (typical of Baroque style) as both a means of discovery and a conceptualizing tool. The existence of multiple points of view in the text, identified by Rousset as one of the defining features of Baroque aesthetics, also comes to manifest itself in the text through a series of revealing episodes in which the Portuguese themselves are seen through 
the perspective of different Others; at times, even Mendes Pinto himself speaks from this decentering perspective. In such moments, the Portuguese come to see themselves as the object of an Other's gaze; they are observed and their origins, knowledge, and customs are brought into question, often in unflattering terms.

The letter sent by the king of Bungo to the prince (nautoquim) of Tanegashima offers a good starting-point for my discussion:

... os dias passados me certificarão homens que vierão dessa terra que tinheis nessa vossa cidade huns tres Chenchicogins do cabo do mundo, gente muyto apropriada aos Iapões, \& que vestem seda \& cingem espadas ... \& que de todas as cousas do mundo que lá vão por fora vos tem dado grandes informações, nas quais afirmão em sua verdade que ha outra terra muyto mayor que esta nossa, \& de gentes pretas \& baças, cousas increiueis ao nosso juizo, pelo que vos pelo muyto como a filho igual aos meus ... que queirais mandar mostrar hum desses tres que me lá dizem que tendes pois, como sabeis, mo está pedindo a minha prolongada doença e má disposição, cercada de dores, \& de muyta tristeza, \& de grande fastio. (cap.135)

The curiosity displayed in this letter by the king of Bungo could easily be applied to the European readers of the Peregrinação, themselves curious to hear of lands, peoples, and societies unknown to them, and experiencing a mixture of amazement and incredulity towards the seemingly unbelievable and unimaginable things contained in it. The episode continues in a way that is also significant for an appreciation of the Peregrinação as a work intended not only to instruct but also to please its readers, as it is Mendes Pinto himself who is chosen to act as the representative of the Portuguese:

[O nautoquim], despois de estar hum pouco pensatiuo na deliberação da escolha, apontando para mim respondeo, este, que he mais alegre \& menos sesudo, porque agrade mais nos Iapões, \& desmalenconize o enfermo, porque grauidade pesada como a destoutro [Christouão Borralho], entre doentes não serue de mais que de causar tristeza \& melanconia, \& acrescentar o fastio a quem o tiuer. (Ch. 135, emphasis mine) 
Though it is important on the level of the plot itself to characterize Mendes Pinto as a captivating personality able to provide joyous entertainment to the Japanese monarch and to help relieve his tedium (fastio), this passage and the subsequent account of the conversation between the king and the author serve to illustrate the literary sophistication and fictionality of the Peregrinação, which essentially inscribes an autobiographical narrative into a broader yet still verisimilar setting (Rubiès and Bacon 23). When Mendes Pinto addresses the king of Bungo for the first time in a self-proclaimed "tosca \& grosseyra reposta" (note the parallel here with the "tosca escritura" label given by the author to his own work in the first chapter), the monarch experiences unexpected and admirable relief from his condition, especially his fastio-a word with rhetorical implications.

Those familiar with the paratextual apparatus of the Peregrinação's editio princeps will no doubt remember the content of the book's 1603 licenças, in which Friar Manuel Coelho describes the Peregrinação as a "historia muyto boa, chea de muyta variedade \& nouidade, por as quais partes ha de contentar muyto, porque a nouidade (segundo diz o Philosopho) deleita, \& a variedade como affirma S. Augustinho tira o fastio" (n.p., emphasis mine). ${ }^{5}$ The word fastio here has, of course, a rhetorical significance: the boredom or tedium of an audience or one's readers. If one catches the polyvalence encoded within the word in the nautoquim's speech, then this seemingly unremarkable episode gains self-reflexive force: Mendes Pinto the traveler, a source of knowledge and a potential entertainer, emerges here as Mendes Pinto the author, while the king of Bungo perfectly embodies an interested readership, captivated by the novelty of Mendes Pinto's material and the varietas of his writing.

Seen more generally, and as Rubiès and Bacon have aptly summarized it, travel writing is quintessentially a genre in which multiple genres converge: "travel literature is ... best described as a 'genre of genres, ${ }^{5}$ since a variety of kinds of literature defined by a variety of purposes and conventions share travel as their essential condition of production" (23). The generic hybridity that characterizes the Peregrinação-it is at once a travel narrative, an autobiographical novel, a picaresque narrative, a biography, a history, an account of diplomatic missions, and even a hagiography_is a paramount example of this phenomenon. This hybridity testifies to the fluid and fluctuating worlds of what Malyn 
Newitt has described as the "informal empire" in Asia (and Mendes Pinto's own subjective experience of it) and points to the significance of generic instability and hybridity as an important mode of conceptualizing human experience and a specific (shifting) worldview. Put another way, the Peregrinação can be said to be "novelistic" in the sense that Bakhtin develops the term (Rabelais; "Epic and the Novel"). Rubiès and Bacon in fact arrive at a conclusion very similar to Baktin's, although through a different disciplinary and theoretical approach.

To understand better the significance of the Peregrinação's generic hybridity for early seventeenth-century readers, one must first move beyond the polemic surrounding the veracity or falseness of Mendes Pinto's account and take a more nuanced approach to the issue of genre. As Marília dos Santos Lopes has argued, the Peregrinação, in spite of early recognition of its status as a largely fictional work, was nonetheless of great documentary value to seventeenth-century European scholars. The "Note to the Reader" found in the 1614 edition of the Peregrinação likewise reveals a certain ambivalence with respect to the classification of Mendes Pinto's text:

... na larga peregrinação que fez por todos os Reinos \& prouincias daquelle grande Imperio Oriental alcançou a noticia de cousas notaueis \& segredos nunca descubertos por outro algũ historiador, as quaes agora se communicam ao mundo nesta breue historia que escreueo em estillo tam vario, que igualmente se podem recrear \& aproueitar com a lição della os curiosos que a lerem, porque ainda que seja de cousas muito nouas \& peregrinas, deuem ser cridas, assi pellas refirir \& affirmar hum Autor de tam conhecida verdade, que a vio, \& palpou com as mãos, \& escreueo com a pena. (n.p.)

The edition's dedication to D. Filipe II likewise reveals some hesitation regarding veracity and genre, although with different implications:

Fernão Mendez Pinto natural deste Reyno, homem de viuo engenho \& felice memoria, escreueo hum liuro de mão em que recupilou as cousas mais notaueis, casos estranhos que vio, \& muitos trabalhos \& perigos que passou na longa peregrinação que fez nas partes do Oriente ... doou por 
morte este largo Itinerario de seus trabalhos .... E como vossa Magestade he protector da dita caza, \& a lição deste liuro de mais de ser varia \& aprasiuel da muita noticia das cousas do Oriente em que vossa Magestade tem tanta parte ... era antes obrigação nossa ... offerecer humildemente a vossa Magestade este liuro. (n.p.)

The first text, which addresses the readers of the work, labels it as a "breue historia" (Francisco de Herrera Maldonado's 1620 Spanish translation contains an "Apologia a favor de Fernam Mendez Pinto y desta Historia Oriental") and Mendes Pinto as a "historiador" and "Autor de tam conhecida verdade." The natural inclination of Mendes Pinto's earlier editors and translators seems to have been to interpret and categorize the Peregrinação in the light of pre-existing genres with relatively clear and well defined boundaries and significant prestige. And yet, early modern readers could simultaneously appreciate the difference, no less than readers today, between the Peregrinação and the traditional historiographical discourse of authors such as Fernão Lopes and Gomes Eanes de Zurara and even that of humanists such as João de Barros, Fernão Lopes de Castanheda or even Damião de Góis, whose Deploratio Lapiannae Gentis (Complaint of the Sami People) and Fides, religio moresque Aethiopum (The Faith, Religion, and Customs of the Ethiopians) were also significant European best-sellers (Earle 347-54). The Peregrinação's clear non-conformity with respect to more traditional historiographical discourse explains in large measure the difficulties that the learned Herrera Maldonado encountered in coming to terms with certain generic and rhetorical aspects of Mendes Pinto's text. It is perhaps for this reason that Herrera Maldonado takes the opportunity in his edition's "Apología a los lectores" to boost his own reputation as a translator and author through strategic textual critique and intervention:

No alcançamos con pequeño trabajo la version deste libro, por hallar su original escrito fuera de las reglas y precetos de toda buena retorica, que como su dueño se preciaua mas de soldado, que de docto, escriuio las jornadas de su vida (admirables por cierto en todo) como las iuan haziendo, sus sucessos, sin mas aduertencia de preambulos, digressiones y figuras, no 
acordandose tanto del deleytable del Poeta, como del vtil de la verdad, y ansi la dexo en esta historia desnuda de todo artificio, sin vsar en su composicion de la variedad hermosa que al escritor encomienda Platon de la oracion perfecta, acabando los periodos con numero cumplido, como agudamente enseña Fauorino de la breuedad mosdesta que dize Horacio, de la claridad, distincion y agudeza que aduierte S. Ambrosio, de la colocacion del sugeto con la materia y forma, como lo quiere Marsilio Ficino, de la vnion y correspondencia de antecedentes y subsequentes que da por necessaria Baldo, de la vnidad y energia de nombre y verbo que pone Cicero, y de la simpatia de las sentencias, pensamientos, discursos y concetos, que pinta tan doctamente Pedro Moselano, para la perfecion del libro porque este nunca pensò su dueño que le viessen tantos ojos, y ansi se contento con hazer a los de sus hijos vna representacion tosca de sus trabajos, verdades brutas (llamemoslas ansi), diamantes por labrar: pero de preciosos fondos y quilates, para que supiessen valerse en los suyos con su exemplo, porque las experiencias agenas siruen de muralla, y de defensa en las aduersidades proprias de quien tan mal sabe librarse la vida. Despues de la del autor se trato de dar estas curiosidades a la estampa, por parecer en todo dignissimas, y viendo estas verdades tan a lo tosco y a lo por labrar en el lenguage y ornamentos historicos, afeyte que haze mas hermosa la verdad, y sube la certeza de quilates, dieron a quien ya he dicho cargo de pulirlas que le parecio que lo estauan bastantemente con diuidirlas en capitulos sin considerar las mayores faltas. $\left(2^{\mathrm{v}}\right)$

Returning to the 1614 editio princeps' dedication to D. Filipe II, an alternating generic categorization of the book is even more evident. The Peregrinação is referred to as a useful manual ("liuro de mão"), a repository of his memories in a synthesis of the knowledge of the "cousas notaueis" which the author acquired in the East (recopilatio). If the first volume of Barros's Décadas "might be characterized as a chronicle-narrative organized on geographical lines" (Lach 190), then the Peregrinação lends itself to being characterized as a narrative organized on the Portuguese commercial and evangelical networks of maritime Asia (Jorge Santos Alves "Fernão Mendes Pinto and the Portuguese 
Commercial Networks"; Barreto). The dedication likewise classifies the book as an "itinerario," an indication that the personal trajectory of Mendes Pintohis "muytos trabalhos \& perigos" and his interests as a man of many tradesimpacts the structural organization of the text; in effect, it links the mapping of these exotic places and societies, their observation, description, and commentary, to the contingency of the author's identity within these networks and the world/s through which he moves. All this, of course, and the subtle combination of fact and fiction, is what grabs the reader and gives the Peregrinação its appeal. In this sense, what the Peregrinação offers is a far cry from the fastidious attention to detail that one finds in later editions of Francesco Sansovino's Historia universal dellorigine e imperio dei Turchi or Giovanni Botero's Relationi universali, both of which drew from Mendes Pinto's knowledge of the East before 1614, when the Peregrinação existed only as a single manuscript copy held in the Casa Pia dos Penitentes in Lisbon (Lopes 267).

\section{From Satire to Polyphony}

Let us now explore more closely the polyphonic character of the Peregrinação. To begin, it is worth noting that critics have tended to address this in relation to the question of whether or not the Peregrinação is in essence a satire. ${ }^{7}$ From my own perspective, reducing Mendes Pinto's text to a satire that is more or less critical of Portuguese imperial ideologies and politics ignores the subtleties of poetic discourse that likewise seem to have mattered greatly to Mendes Pinto and his readers. After all, even texts that emerge within an imperial setting and which are written by authors who support the idea of empire can certainly voice a critique of the crude, pragmatic, and often violent realities of its implementation-across borders and across time. This is the power of texts composed with greater discursive complexity-subtleties that readers of, for example, Luís de Camões, Alonso de Ercilla, Alvar Núñez Cabeza de Vaca, and Diogo do Couto's O Soldado Prático can, similarly, certainly appreciate. It should be noted that in the final chapter of the Peregrinação the different levels of the ideal and the reality of the imperial project are symbolically represented in the system of government and its shortcomings. The figure of the absolute king, a center of power, is imagined as a "fonte de água pura" (Ch. 226). And 
yet this representation of absolute centrality and power is partially undone by reference throughout the book to the corrupt vessels (ministers, officials, and representatives) who emerge as criminals-a point also made by Bartolomé de las Casas in the prologue to his Brevísima relación (1552), in which the power of the monarch is placed into question by the very expanse of his empire and the impossibility that any mortal king may know everything that occurs in it:

\begin{abstract}
Muy alto, y muy Poderoso Señor: Como la Providencia divina tenga ordenado en su mundo, que para direccion y comun utilidad del linage humano se constituyesen en los reynos y pueblos reyes como padres y pastores, segun los nombra Homer, y por consiguiente sean los mas nobles y generosos miembros de las repúblicas; ninguna duda de la rectitud de sus ánimos reales se tiene, o con recta razon se debe tener, que si algunos defectos, daños y males se padecen en ellas, no ser otra la causa sino carecer los reyes de la noticia dellos, los quales, si les constassen, con sumo estudio y vigilante solercia extirparian. (5)
\end{abstract}

At the heart of Las Casas' address to the crown prince Felipe (who would become king of Spain and, in 1580, of Portugal) is the idea that while monarchs may be essentially faultless, the fact that they are also not omniscient nonetheless opens them up to various "defectos, daños y males."

Mendes Pinto's nod to political theory reminds us that it is important to understand the polyphonic character of his text not just within the specific context of the Portuguese presence in Asia, but also as part of a deeper account of early modern representations of the world and the place of the self in that world. For Mendes Pinto as with his European readers, the world was no longer a straightforward geographical space, but rather an unstable and misleading scene of human events:

Deos \& elle [mundo] estão sempre muyto differentes, assi nas obras, como nas condições com que as fazem, porque o mundo não pode dar cousa que boa seja por ser pobre \& misero, \& Deos he muyto rico, \& amigo dos pobres ..., o mundo vingatiuo, \& Deos paciente, o mundo ruym, \& Deos muyto bom, o 
mundo comedor, \& Deos abstinente, o mundo reuoltoso e murmurador, \& Deos pacifico \& sofredor, o mundo mentiroso \& trapaceyro para os que são seus, \& Deos verdadeyro \& claro \& doce \& suaue aos recolhidos na sua oração, o mundo sensual \& auarento, \& Deos liberal \& limpo sobre tda a limpeza do sol \& das estrellas ..., o mundo cheyo de diuersas opiniões no falso fumo de sua vamgloria, \& Deos puro \& constante em sua verdade ..., o mundo doudo \& ignorante, \& Deus sabeduria pura de toda a verdade" (Ch. 81)

The dysphoric description of the world's multiplicity is constructed and given cohesion in this passage as the embodiment of a person endowed with agency, cast in contrasting juxtapositions (or conceitos in the Baroque sense) to the transcendent world of "Deus ... constante." Equally important is the location of the passus: it appears in the chapter following the dramatic shipwreck in which António de Faria mysteriously disappears. ${ }^{8}$ The episode of Faria’s shipwreck therefore operates as a powerful meditation on the limits of human action in the face of a "mundo trapaceyro \& mentiroso," and as a scene of "manifest perdition" for those who pursue worldly glory and riches in immoral terms. ${ }^{9}$ It is thus not only the representation of human life as a theatrum mundi, nor is the world merely a locus of human action riddled with uncertainty; rather it is a spatial and temporal progression, and events in the Peregrinação are notoriously subject to change and contingency: "são successos da fortuna, \& do tempo que sempre custumarão trazer consigo estas variedades" (Ch. 152, emphasis mine).

The Peregrinação's theorization of the world as passage consecrates two seemingly opposing yet conciliatory reactions: skepticism of and a fervent belief in the transcendent as a haven for the "bicho da terra tão pequeno" (Camões, Os Lusíadas I.106:8). ${ }^{10}$ The dramatic disappearance of António Faria, an excessive hero who through his inquisitive spirit and military prowess defies the limits of reason and morality, is to be interpreted at once as encompassing and surpassing the specific case of a critique of Portuguese imperial ambition (cap. 79). In his review of Josiah Blackmore's Manifest Perdition, Hélio Alves notes the existence of a prestigious literary tradition, imbibed by the early-modern shipwreck accounts, that amounts to a kind of "uniform code of vituperation" (1218) and surpasses the historical specificity of shipwrecks in imperial 
contexts. Following Alves' line of reasoning, the António Faria episode stands as an exemplary case of hubris and punishment for the folly of clinging to any form of human ambition and vanity.

From another perspective, and taking the lead from Eduardo Lourenço's portrait of Mendes Pinto as a "penitent" recently reworked by Vincent Barletta ("Masochistic Ritual") as a form of imperial perversion, we might focus on the author's trials and tribulations in his travels (where humiliations, physical violence and suffering frame the path of human experience and knowledge) as an attempt to prompt readers to seek salvation and put their faith in God. Hence the most important narrative sequence of the Peregrinação's final section coincides with the death of Saint Francis Xavier, a narrative counterpoint to Faria's folly.

Any attempt on Mendes Pinto's part to prompt his readers to act depends upon first arousing their sympathia. In spite of his criticism of certain aspects of the work, Herrera Maldonado seems to engage in just such a project when he presents the Peregrinação as an artful panacea and agudeza de ingenio for the ills of the world:

cosas de risa hallara aqui el melancolico con los disparates del gentiles, el grave discursos levantados en su modo de gobierno, admiracion los doctos en la variedad de citas y opinions, consuelos el mas triste con agenas penas, que con esas olvidan las que son proprias, el discreto agudezas en el proceder de aquellas gentes de Asia; el desdichado exemplos con algunos lastimosos, el perseguido alivios, riquezas el avariento y fuerzas el valiente y todos hallaran algo, solo el necio no hallara nada. (v)

In this passage, the Spanish translator emphasizes the pathetic appeal of the Peregrinação for a wide audience along a broad spectrum of human emotions.

Returning to the question of skepticism in the Peregrinação, the surfacing of doubt with respect to the self-proclaimed moral superiority of Europeans is, in my view, more subtle, unsettling, and far-reaching than a mere critique of Portuguese expansionism. In the Peregrinação, categories such as "barbarian" and "civilized" are consistently viewed in relational terms, and their relative truth is explored in episodes where the decentering of power relations between 
the Portuguese and their Asian counterparts is recast in terms that draw from the very practices and commonplaces of polyphonic colonial discourse.

There are abundant accounts in the Peregrinação of encounters between Europeans and "naked savages," and readers of Pero Vaz de Caminha's Carta do descobrimento do Brasil will recognize the symbolic and ideological reach of such representations. ${ }^{11}$ In several occasions of shipwreck and misfortune in the Peregrinação, the text focuses on the imposed nudity of the Portuguese when they encounter local populations. After a deadly shipwreck off the Ryukyu Islands, for example, the narrator describes the condition of the Portuguese survivors in these terms: "E estando assi todos neste trabalhoso trance, chegarão a nós seis de cauallo \& vendonos assi nus, \& sem armas, \& cos joelhos em terra, \& duas molheres mortas diante de nòs, ouuerão tamanha piedade, que voltando os quatro delles para a gente de pè que vinha atras, os fizerão ter a todos, sem consentir que nenhum nos fizesse mal" (Ch. 138, emphasis mine). It is important to keep in mind, as well, that nudity in the Peregrinação is not a prelapsarian image or a utopian representation of the "noble savage" such as what would emerge in later seventeenth-century European discourse (Pagden). Mendes Pinto makes it clear that in the eyes of the local populations, nudity is also seen as an "unreasonable" condition: "respondemos que ... nos perderamos com huma grande tormenta auia quinze dias, sem saluarmos mais que aquellas miseraueis carnes assi chagadas \& nuas como as vião ... elles todos quatro nos responderão, razão he que se dé a essas vossas nuas carnes o que com tantas lagrimas pedis" (Ch. 81).

As with the many shipwreck narratives anthologized in the História Trágico-Marítima, the nudity of the shipwrecked Portuguese confirms inferiority (albeit circumstantial rather than cultural), dependency, and ultimately mortality. The experience of enslavement is also well represented in the Peregrinação, highlighted for its readers in both the introductory chapter ("fui treze vezes cativo, e dezassete vendido") and the final one ("fui treze vezes cativo, e dezasseis vendido"). Likewise, the first-hand experience of slavery is not just glossed over but explored in detail throughout the book (especially in chapters five and 138-41), in yet another example of the "multiple voices" and perspectives encoded within the Peregrinação, as well as their decentering power. 


\section{Barbarism Begins at Home}

The Peregrinação's narrator does not hesitate to label the Chinese as "barbarians" in spite of their obvious sophistication: "ajudados do seu favor diuino, se dé a entender a estes barbaros a verdade da nossa santa Fé Catholica, da qual elles por seus peccados andão tão alheyos que zombão de quanto lhe dizemos disto, \& chegão a tanto barbarismo e desatino, que dizem que só em ver o rosto ao filho do Sol ... está ser huma alma benauenturada" (chap. 108). In fact, with the exception of episodes of extreme violence, in which Mongols, Burmese, and Siamese are referred to as barbarians (e.g., caps. 117 and 203), the other occasions where the term occurs are few and always strategically placed. Mendes Pinto uses the term, for example, to refer to a difference of creed in Japan (cap. 203), and he also makes use of it to describe both himself and Portugal:

\footnotetext{
E como a natureza desta nossa nação Portuguesa é sermos muito afeiçoados a nossos pareceres, houve aqui entre nós todos oito tanta diferença e desconformidade de opiniões ... que quase nos matávamos uns aos outros, de maneira que, por ser assaz vergonhoso contar o que se passou, não direi mais senão que o Necodá da lorcha que ali nos trouxe de Uzangué, espantado de nosso barbarismo, partiu muito enfadado. (cap. 132)
}

Mendes Pinto applies the term "barbarismo" to himself and to the Portuguese in this passage, in the process projecting the subjective reaction of what emerges, implicitly, as the civilized Asian Other in the episode. The boat captain's "espanto" emerges not from a sense of wonder at the novelty of Portuguese mores, but rather by a sense of perplexity that manifests itself as an outright moral rejection.

Equally significant is the fact that the only episode of actual cannibalism in the Peregrinação is committed by members of a Portuguese crew:

E ha ja quatorze dias que andamos sobre estes paos, sem em todos elles comermos mais que hum cafre meu que nos falleceo, com que todos nos sustentamos oito dias, \& inda esta noite nos fallecerão dous Portugueses que não quisemos comer, tendo disso bem necessidade, porque $[s i c]^{12}$ sem 
duuida nos pareceo que oje ate a menham acabassemos com a vida estes miseraueis trabalhos em que nos viamos. (Ch. 33)

Mendes Pinto presents the consumption of the African slave's body as an acceptable act in the face of necessity, thus opening to discussion the acceptable limits of, and conditions for, the practice of cannibalism. On one hand, the term cafre points to a member of a "primitive" community of non-Christians who was in effect the narrator's legal property. ${ }^{13}$ The reason for the acceptability of cannibalism in this case, however, hangs in the air. Is it a difference of skin color that justifies the behaviour of the Portuguese? A question of legal status? Do they feel free to eat the cafre because he was not a Christian? Would the Portuguese have eaten a dead Muslim under similar circumstances? Or do both factors concur simultaneously in shaping the identity of the cannibal self and the cannibalized Other? The strategy of denigrating the African or American Other as a cannibal, frequent in colonial discourse, is here (as in Montaigne) redeployed.

\section{The Portuguese as Baroque Spectacle in Japan}

My final point of analysis is an exploration of spectacle. Within the Peregrinação, there are numerous examples of an interest in the festivals and celebrations of the local populations, and these are consistently full of rich sensorial evocations of exoticism and ethnographic interest. My concern, however, is on a very different spectacle-theater itself-that on one important occasion operates as a powerful locus of parody. In a captivating chapter almost at the end of the book (Ch. 223), Mendes Pinto presents readers with a detailed account of the sophisticated and lavish banquet offered by the queen of Bungo to her husband and members of her household. A group of five Portuguese merchants (Mendes Pinto included) is also invited to join the party, and their table etiquette comes across as "uncivilized," if patronizingly entertaining to their Japanese hosts:

[el-Rei] nos rogou que por amor delle quisessemos perante elle comer com a mão, assi como faziamos em nossa terra, porque folgaria a Raynha de nos ver ... porem os ditos e as galantarias que as damas nos dezião \& as 
zombarias que fazião de nòs quando nos virão comer com a mão, forão de muyto mór gosto para el Rey \& para a Raynha que quantos autos lhe puderão representar, porque como esta gente custuma comer com dous paos ... tem por muyto grande çugidade fazelo com a mão como nos custumamos.

Not content with this, one witty princess gathers a crew of ladies from the queen's household, and together they put on a "farça sobre o material de que trataua" (i.e., the manners of the Portuguese at the dinner table), much to the annoyance and strained outrage ("afronta") of the party of five Portuguese men, who as the night goes on become a source of entertainment as the target of female "graças \& zombaria."

Mendes Pinto categorizes the women's play as a farça (not an auto), and the comic denouement of the play, as well as the spectacle of actresses accompanied by music, dancing, and singing (complete with sumptuous clothing), all serve as a disavowal of Portuguese cultural, commercial, and imperial aspirations. The plot is easily summarized. An older Japanese merchant presents himself before a powerful king and begs for his generosity, as the former wishes to sell to the Portuguese who have just arrived there. His goods will be of great use to the Portuguese, he argues, given the "grande aleijão em que se vem continuamente," and with the profits he will ensure the livelihood of his many children. The king decides to request a sample of the goods, and if they are indeed deemed useful to the Portuguese, then they will purchase them directly from the king himself. This is the moment in the play in which things begin to change for the Portuguese: the sons of the merchant bring forth bundles, which they proceed to unwrap, and when dozens of wooden arms spill out before the king, the merchant speaks for his would-be Portuguese clients: “... pois que a natureza por nossos peccados nos sojeitara a nos outros a miseria tão çuja que necessariamente as nossas mãos auião sempre de andar fedendo ao peixe, ou à carne, ou ao mais que comiamos com ellas, nos armaua muito aquella mercadoria, porque enquanto nos seruissem humas mãos se lauarião as outras." The king and queen laugh heartily at this joke at the expense of their Portuguese guests, but upon noticing the vexation of the latter, the king begs their pardon, claiming that "porque a princesa sua filha visse quamanho bem elle queria 
aos Portugueses lhe dera aquelle pequeno de passatempo, de que nos somente como irmãos seus foramos participantes." The witty remark brings the spectacle to an end.

The farce at the court in Bungo (a striking example of the Bakhtinian carnivalesque) represents quite clearly a stereotypical image of the Portuguese as an uncivilized nation of paupers and merchants, an image that had already caught hold in Japan by that time, as Mendes Pinto attests: "eu já em Tanixumaa tinha visto outra farça que se teue com Portugueses semelhante a esta, \& por algumas vezes a tinha visto tambem noutras partes" (chap. 223). In contrast to the motley Portuguese, the king (who retains direct control of all trade with the foreigners), the merchant, and the merchant's sons are all dressed in beautiful clothing and golden accessories befitting their status. Finally, the spectacle of music, singing and dancing is sophisticated and entertaining: "numa dança ao seu modo muyto bem conceertada, ao som de duas arpas \& huma viola darco, \& de quando em quando dezião em trouas com falas muyto suaues \& muyto para folgar de ouuir." Portuguese readers of the Peregrinação would likely have reacted to this stereotypical performance of their own alterity with the same feelings of outrage and shame experienced by the Portuguese travelers in the book.

This episode in the Peregrinação is a telling example of the extreme uneasiness and anxiety linked to the process of expanding horizons and searching for identity that accompanied the cultural contacts between the Europeans and overseas peoples. To conclude, I should point out that by no means is this complex response specific to the Peregrinação or, indeed, the Portuguese context. The shift in perspective operated recurrently by Mendes Pinto in his book, the representation of the self which is constructed by mediation of the different Others who speak out in the Peregrinação, and ultimately the responses prompted by this disavowing representation all have parallels in the work of other Iberian intellectuals. As Barletta has recently argued in Death in Babylon, while contributing to the "writing of empire," these intellectuals subtly disturb the dynamics of imperial power and cast a cloud upon the claims to temporal glory and the desire for immortality. Such is the sophistication and complexity of the Peregrinação. Like Holbein's painting, it challenges its readers to look at the world and themselves from a range of different perspectives, and through 
different semiotic means. My analysis of three aspects of Baroque poeticsgeneric hybridity, polyphony, and spectacle-as means to understand and conceptualize notions of "world" and "self" as developed in the Peregrinação is at once a response to new critical approaches to Mendes Pinto's text and an invitation to approach this and other texts associated with Portuguese empire and exploration from different disciplinary and methodological footing.

\section{Notes}

1 Seixo, Poéticas da Viagem; "Postcolonial views." Seixo's work is inspirational in several respects, and the present essay is in many ways indebted to her.

2 While it is true that Homi Bhaba's classic The Location of Culture did much to open up, within the loose framework of postcolonial studies, the questions around which these questions of "world" and "selfhood" revolve, in the present analysis I rely more directly on discursive and generic issues that emerge from Mikhail Bakhtin's Problems of Dostoyevsky's Poetics.

3 All citations from the Peregrinação follow the text of Jorge Santos Alves's 2010 critical edition. Due to the rarity of this edition, however, I consider it more useful to the reader to reference the Peregrinação's short chapters rather than the page number in Alves's edition.

4 I should point out that while Zoltán Biedermann's index of the Peregrinação is a powerful tool for scholars of various disciplines, my analysis of concepts such as "mundo," "metropolis," "bárbaro," "fastio," and "nudez," as well as the use of expressions such as "cabo do mundo" and "desconfiado/os" stems from searches carried out through a digitized version of the 1614 editio princeps. Nonetheless, much of this research was initially inspired by Biedermann's inclusion of "canibalismo" within his index.

5 Mendes Pinto died in 1583, and it would be another thirty years before his manuscript was printed. Critics have speculated about the reasons for this substantial delay, especially considering the importance of this work for the many readers with an interest in the Orient. We know that the Peregrinação circulated in manuscript form in the Iberian Peninsula, and was seen as a valuable source of information; and yet, once deposited into the care of the Casa Pia dos Penintentes in Lisbon by the author or his daughters, the manuscript underwent a severe revision by an unclear number of people (including Francisco de Andrada) to pass the scrutiny of censorship. The extent of this revision is believed to be significant, despite the slim possibility of finding manuscript evidence that might help critics to reconstruct the original text. In 1614 the editio princeps of the Peregrinação came to light, thanks to the patronage and sponsorship of the Faria family (with family ties to António de Faria): it seems that despite the interest of the Jesuits and Felipe II, neither the Society nor the crown invested in the publication of the book, most likely due to the Casa Pia dos Penitentes owning publication rights for the first ten years.

6 Yet another occasion where Rubiès and Bacon arrive at conclusions on the nature of travel writing which are similar to those proposed by Bakhtin about the novel as a genre.

7 The critical debate surrounding the satirical mode of the Peregrinação has been marked by those, such as António José Saraiva and Rebecca Catz (Sátira Social; Fernão Mendes Pinto) who see in the text a critique of the Portuguese empire, and those, such as Aníbal Pinto 
de Castro, João-David Pinto Correia (Rev. of Fernão Mendes Pinto), Armando Cortesão, and Eduardo Lourenço, who have a more ambivalent sense of the book.

8 João-David Pinto Correia argues that Faria "had to die" in the shipwreck for the purposes of the narrative and its intended objective; however, there is also evidence that he was alive many years later ("Construção do colectivo" 179).

9 Blackmore; Lanciani; Seixo, Poéticas da Viagem.

10 Upon being found by the subjects of the king of Ryukyu after a shipwreck, the narrator describes his hesitation to accept their generous offers of help, and his general sense of pessimism, in eloquent terms: "as quais consolações, embora nas mostras de fora nos parecessem algum tanto piedosas, contudo não nos satisfizeram nada, porque já a este tempo estauamos tão desconfiados da vida, que ainda que nolas dissessem pessoas em que tivéssemos muita confiança, dificilmente acreditaríamos" (Ch. 138).

11 For more on Vaz de Caminha's account of Brazil, see Sadlier 9-62.

12 I believe there are strong reasons to suggest a revision of the critical edition of the passus: in the printed edition "por" and "que" (commonly abbreviated as "q") are to be understood as two separate words despite their proximity on the printed page: "fallecerão dous Portugueses que não quisemos comer, tendo disso bem necessidade, por que ["pelo qual", not causal "porque"] sem duuida nos pareceo que oje ate a menham acabassemos com a vida.

13 For a synthesis of the term cafre's significance (and its discrepancies according to different authors), see Pereira; Bluteau; and Feijó.

\section{Works Cited}

Alves, Hélio. Rev. of Manifest Perdition: Shipwreck Narrative and the Disruption of Empire, by Josiah Blackmore. Renaissance Quarterly 56.4 (2003): 1218-19. Print.

Alves, Jorge Manuel dos Santos. "Fernão Mendes Pinto and the Portuguese Commercial Networks in Maritime Asia (1530-1550)." Fernão Mendes Pinto and the Peregrinação. Ed. Jorge Manuel dos Santos Alves. 4 vols. Lisbon: Fundação Oriente/Imprensa Nacional Casa da Moeda, 2010. I: 89-119. Print.

— ed. Fernão Mendes Pinto and the Peregrinação. 4 vols. Lisbon: Fundação Oriente/ Imprensa Nacional Casa da Moeda, 2010. Print.

Bakhtin, Mikhail. Problems of Dostoevsky's Poetics. Trans. Caryl Emerson. Minneapolis: U of Minnesota P, 1984. Print.

—. Rabelais and His World. Trans. Hélène Iswolsky. Bloomington, IN: Indiana UP, 1993. Print. . "The Epic and the Novel: Towards a Methodology for the Study in the Novel." The Dialogic Imagination. Ed. Michael Holquist. Austin, TX: U of Texas P, 1981. 3-40. Print.

Barletta, Vincent. Death in Babylon: Alexander the Great and Iberian Empire in the Muslim Orient. Chicago: U of Chicago P, 2010. Print.

"Masochistic Ritual and Rebirth in Fernão Mendes Pinto’s Peregrinação." ellipsis 7 (2009): 53-70. Print.

Barreto, Luís Filipe. "Fernão Mendes Pinto and the Jesuit Connection." Fernão Mendes Pinto and the Peregrinação. Ed. Jorge Manuel dos Santos Alves. 4 vols. Lisbon: Fundação Oriente/Imprensa Nacional Casa da Moeda, 2010. I: 55-87. Print. 
Bhabha, Homi. The Location of Culture. Oxford: Routledge, 1994. Print.

Bluteau, Rafael. Vocabulario Portuguez e Latino. Coimbra and Lisbon: Colégio das Artes, Sylva and Sylva, and Patriarcal Officina da Musica, 1712-1728. Print.

Biedermann, Zoltan. "Index." Fernão Mendes Pinto and the Peregrinação. Ed. Jorge Manuel dos Santos Alves. Vol. 4. Lisbon: Fundação Oriente/Imprensa Nacional Casa da Moeda, 2010. Print.

Botero, Giovanni. Relationi universali. Venice: Angelieri, 1599. Print.

Boxer, Charles R., ed. and trans. The Tragic History of the Sea. Minneapolis, MN: U of Minnesota P, 2001. Print.

Caminha, Pêro Vaz de. O descobrimento do Brasil: a carta. Ed. Sílvio Castro. Porto Alegre: L\&PM/História, 1985. Print.

Camões, Luís de. Os Lusíadas. [1572]. Porto: Porto, 2006. Print.

Casas, Bartolomé de las. Brevísima relación de la destruición de las Indias. Ed. André Saint-Lu. Madrid: Cátedra, 2005. Print.

Castro, Aníbal Pinto de. Introdução à Peregrinação de Fernão Mendes Pinto. Porto: Lello and Irmão, 1984. Print.

Catz, Rebecca. A sátira social de Fernão Mendes Pinto: análise crítica da Peregrinação. Lisbon: Prelo, 1978. Print.

—. Fernão Mendes Pinto: Sátira e anti-cruzada na Peregrinação. Lisbon: Instituto de Cultura e Língua Portuguesa, 1981. Print.

Correia, João-David Pinto. "A construção do colectivo na Peregrinação: percursos e significado." O discurso literário da Peregrinação. Ed. Maria Alzira Seixo and Christine Zurbach. Lisbon: Cosmos, 1999. 169-88. Print.

— Rev. of Fernão Mendes Pinto: Sátira e Anti-cruzada na Peregrinação, by Rebecca Catz. Revista Colóquio/Letras 74 (1983): 85-86. Print.

Cortesão, Armando. "Fernão Mendes Pinto não Era de Origem Judaica." Seara Nova 842 (1943): 89-91. Print.

Couto, Diogo do. O Primeiro Soldado Prático. Ed. António Coimbra Martins. Lisbon: Comissão Nacional para as Comemorações dos Descobrimentos Portugeuses, 2001. Print.

Earle, Thomas F. “Deploratio Lappiannae Gentis: Text and Translation.” Humanitas 58 (2006): 347-67. Print.

Feijó, João de Morais Madureira. Orthographia, ou Arte de escrever, e pronunciar com acerto a Lingua Portugueza. Lisbon: Rodrigues, 1734. Print.

Greene, Roland. Five Words: Critical Semantics in the Age of Shakespeare and Cervantes. Chicago: U of Chicago P, 2013. Print.

"The Global I-Rethinking an Early-Modern Convention." Stories and Portraits of the Self. Ed. Helena Buescu and João Ferreira Duarte. Amsterdam: Rodopi, 2007. 161-74. Print.

Herrera Maldonado, Francisco de, ed. and trans. Historia oriental de las peregrinaciones de Fernan Mendez Pinto. 1620. Madrid: Flamenco, 1627. Print.

Lach, Donald F. Asia in the Making of Europe. Vol. 1 (The Century of Discovery). Chicago: U of Chicago P, 1994. Print.

Lanciani, Giulia. Sucessos e naufrágios das naus portuguesas. Lisbon: Caminho, 1997. Print. 
Lopes, Marília dos Santos. "Peregrinação by Fernão Mendes Pinto: a Source of Knowledge." Fernão Mendes Pinto and the Peregrinação. Ed. Jorge Manuel dos Santos Alves. 4 vols. Lisbon: Fundação Oriente/Imprensa Nacional Casa da Moeda, 2010. I: 257-69. Print.

Lourenço, Eduardo. "A Peregrinação e a crítica cultural indirecta." Peregrinação. By Fernão Mendes Pinto. 2 vols. Ed. Fernando Ribeiro de Mello. Lisbon: Afrodite, 1971. xci-cii. Print.

Margarido, Alfredo. "La multiplicité des sens dans l'écriture de Fernão Mendes Pinto et quelques problèmes de la littérature de voyages au XVIe siècle." Arquivos do Centro Cultural Português 11 (1990): 159-99. Print.

Mendes Pinto, Fernão. Peregrinaçam. Lisbon: Crasbeeck, 1614. Google Book Search. Web. 15 January 2014.

Montaigne, Michel de. "On the Cannibals." The Complete Essays. Trans. and ed. M.A. Screech. London: Penguin, 2003. 228-41. Print.

Newitt, Malyn. "Formal and Informal Empire in the History of Portuguese Expansion." Portuguese Studies 17 (2001): 1-21. Print.

Pagden, Anthony. The Fall of Natural Man: The American Indian and the Origins of Comparative Ethnology. Cambridge: Cambridge UP, 1982. Print.

Pereira, Bento. Thesouro da lingua portugueza. Évora: Academia, 1697. Print.

Rousset, Jean. La littérature de lâge baroque en France: Circé et le paon. Paris: Corti, 1953. Print.

Rubiès, Joan Pau. Travel and Ethnology in the Renaissance: South India through European Eyes, 1250-1625. Cambridge: Cambridge UP, 2000. Print.

— and Francis Bacon. "Travel Writing as a Genre: Facts, Fictions and the Invention of a Scientific Discourse in Early Modern Europe." The International Journal of Travel and Travel Writing 1.1 (2000): 5-33. Print.

Sadlier, Darlene. Brazil Imagined: 1500 to the Present. Austin, TX: U of Texas P, 2010. Print.

Sansovino, Francesco, ed. Dell'historia universale dellorigine et imperio dei Turchi. 2 vols. Venice: Sansovino, 1560. Print.

Saraiva, António José. "Fernão Mendes Pinto ou a Sátira Picaresca da Ideologia Senhorial." História da Cultura em Portugal. 3 vols. Lisbon: Jornal de Foro, 1962. 343-96. Print.

Seixo, Maria-Alzira. Poéticas da Viagem na Literatura. Lisbon: Cosmos, 1998. Print. ."Postcolonial Views in the Constitution of Literary Colonial Discourse." The Paths of Multiculturalism: Travel Writings and Postcolonialism. Ed. Maria-Alzira Seixo, John Noyes, Graça Abreu, and Isabel Moutinho. Lisbon: Cosmos, 2000. 303-12. Print.

Wojciehowski, Hannah Chapelle."The Queen of Onor and her Emissaries: Fernão Mendes Pinto's Dialogue with India." Emissaries in Early Modern Literature and Culture: Mediation, Transmission, Traffic, 1550-1700. Ed. Brinda Charry and Gitanjali Shahani. Farnham, UK: Ashgate, 2009. 167-92. Print. 
Catarina Barceló Fouto holds the post of Lecturer in Portuguese Studies at King's College-London (2011). Her research and teaching interests include the study of medieval and early-modern Portuguese texts (in Portuguese, Spanish and Latin) and culture. She is the co-editor of a special number of the Hispanic Research Journal ("Negotiating Power in the Literatures of the Iberian Inquisitions: Courts, Crowns and Creeds"), and of the forthcoming volume, The Reinvention of Theatre in SixteenthCentury Europe: Traditions, Texts and Performance (Legenda). Amongst others, she has published and presented papers on António Ferreira, Sá de Miranda, Camões, Diogo de Teive and André de Resende. Her survey of Portuguese Neo-Latin literature and of "Anti-Erasmianism in Portugal" will appear, respectively, in The Oxford Handbook of Neo-Latin and Dicionário dos Antis: A Cultura Portuguesa em Negativo. 